http://dx.doi.org/10.11646/phytotaxa.162.4.10

\title{
Notes on Early Land Plants Today. 51. Validation of Schistochilopsis hyperarctica (Scapaniaceae, Marchantiophyta)
}

\author{
NADEZDA A. KONSTANTINOVA ${ }^{1}$, LARS SÖDERSTRÖM ${ }^{2, *}$, ANDERS HAGBORG ${ }^{3} \&$ MATT VON KONRAT $^{3}$ \\ ${ }^{I}$ N.A. Avrorin Polar-Alpine Botanical Garden - Institute of Kola SC RAS, 184236 Kirovsk-6, Russia; nadya50@list.ru \\ ${ }^{2}$ Department of Biology, Norwegian University of Science and Technology, N-7491 Trondheim, Norway; lars.soderstrom@ntnu.no \\ ${ }^{3}$ Science and education, The Field Museum, 1400 South Lake Shore Drive, Chicago, IL 60605-2496, USA; hagborg@pobox.com, \\ mvonkonrat@fieldmuseum.org \\ "Author for correspondence
}

Lophozia hyperarctica (Schuster 1961: 967) was described from Ellesmere Island, Canadian Arctic. However, the author stated that the species occurred in very small patches and made a collection of them in a small area, but giving every small collection a separate collection number, thus making several gatherings out of them. When describing the species he used 5 differently numbered gatherings stating "these five collections extremely skimpy, coming from the same locality and to be considered the collective representing the type" thus violating ICN Art. 41.2 (McNeill et al. 2012). This mistake was overlooked when transferring the taxon to Massula hyperarctica (R.M.Schust.) Schljakov (1972: 318), Massularia hyperarctica (R.M.Schust.) Schljakov (1985: 232), Schistochilopsis hyperarctica (R.M.Schust.) Konstant. in Konstantinova \& Vasiljev (1994: 125) and Lophozia grandiretis var. hyperarctica (R.M.Schust.) Damsholt (2008: 98). The species is validated here.

Schistochilopsis hyperarctica Konstant. et L.Söderstr., sp. nov.

Based on:-Lophozia hyperarctica R.M.Schust., Canad. J. Bot. 39: 967, 1961 (Schuster 1961) nom. inval. (Art. 40.2; based on more than one gathering). Type:-CANADA. Ellesmere: Alert Weather Station, R.M.Schuster 35142 (F!, holotype). Note:-The reference to the description in Schuster (1961: 967), together with the reference to the single gathering selected here, validates the taxon.

\section{Acknowledgements}

The Early Land Plants Today project (ELPT) has been generously supported in part by the Global Biological Information Facility (GBIF) Seed Money Award No.2007-41, activities facilitated in part by funding from the Biodiversity Synthesis Center of the Encyclopedia of Life (BioSynC), partial funding from the National Science Foundation (Award No's 0749762, 1115002), the Warwick Foundation, and the Negaunee Foundation.

\section{References}

Damsholt, K. (2008) Liverworts collected during the Norwegian east Greenland expeditions 1929-1933. Lindbergia 33: $92-113$.

Konstantinova, N.A. \& Vasiljev, A.N. (1994) On the hepatic flora of Sayan Mountains (south Siberia) [K flore pečenočnikov Saân (ûžnaâ Sibir')]. Arctoa 3: 123-132.

McNeill, J., Barrie, F.R., Buck, W.R., Demoulin, V., Greuter, W., Hawksworth, D.L., Herendeen, P.S., Knapp, S., Marhold, K., Prado, J., Prud'homme van Reine, W.F., Smith, G.F., Wiersema, J.H. \& Turland, N.J. (2012) International Code of Nomenclature for algae, fungi and plants (Melbourne Code) adopted by the Eighteenth International Botanical Congress Melbourne, Australia, July 2011. Regnum Vegetabile 154: 1-240.

Schljakov, R.N. (1972) Massula (K. Müll.) Schljak. - novyj rod kompleksa Lophozia Dum. s. 1. [Massula - genus novum complexus Lophozia Dum. s. 1.]. Novosti Sistematiki Nizših Rastenij 9: 310-318.

Schljakov, R.N. (1985) Novoe nazvanie i novye kombinacii dlâ roda Massula Schljak. [Nomen novum et combinationes novae pro genere Massula Schljak.]. Novosti Sistematiki Nizših Rastenij 22: 231-232.

Schuster, R.M. (1961) Notes on nearctic Hepaticae. XVIII. New Lophoziaceae from the arctic archipelago of Canada. Canadian Journal of Botany 39: 965-992.

http://dx.doi.org/10.1139/b61-081 